\title{
A pair of electronic devices for detecting restricted-band audio and ultrasonic frequencies
}

\author{
DAVID L. HOATS \\ Edward R. Johnstone Training and Research Center, Bordentown, New Jersey 08505
}

\begin{abstract}
Two devices, the bandpass active filter and the phase-locked loop, are briefly discussed, with applications of each. The reader is directed to further sources of information on theory and practical circuitry as well as to sources of components and finished units.
\end{abstract}

Electronic filters have found use in the behavioral sciences for detecting restricted-band audio-frequency and ultrasonic animal vocalizations (Barfield \& Geyer, 1972; Morgret, 1972; Thor, Ghiselli, \& Wilson, 1973), for processing human speech patterns (Rogers, Scherer, \& Rosenthal, 1971), and in the processing of bioelectric potentials (Helmer, 1975; Paskewitz, 1971; Rouse, 1974). The successful use of the electronic filter as a speech processor suggests its application to overcome some of the difficulties encountered in the use of voice keys (Kapuzinski \& Rosenquist, 1973).

The behavioral scientist without extensive training in electronics may find difficulty in understanding the instrumentation used in the studies cited, since information on theory and practice in filter design is scattered throughout the technical literature and is frequently written in unintelligible technical jargon. Should he/she become interested in performing such experiments, the scientist must have sufficient information either to build filters or to specify their purchase from commercial sources. Comprehensible sources of such information are found in Tables 1 and 2.

The type of filter most widely used in behavioral research has been the operational amplifier bandpass filter, an analog device that isolates, and delivers intact at the output, a narrow-band sample from all the frequencies appearing at the input. In applications where simple detection of the output sample is desired (e.g., in animal vocalization studies), the signal from the filter must be further processed to provide a digital output (a voltage level or a relay closure) to operate a counter. For such detection applications, a serious rival to the analog filter should be the Signetics 567 phaselocked loop integrated circuit. The phase-locked loov operates by comparing the frequency of a signal appearing at its input to an internally-generated signal. When the frequencies of the two signals correspond, the phase-locked loop changes the voltage level of its output. This voltage level change may be used as a direct digital output or to drive other output devices (up to

The writer wishes to thank Herman $H$. Spitz, Donald $H$. Thor, John J. Winters, Jr., and Emilia A. Winters for their helpful suggestions.

$100 \mathrm{~mA})$. Further advantages of the phase-locked loop are low price, wide voltage range (4-10 V), acceptance of very low-level input signals ( $2 \mathrm{mV}$ minimum), and easy incorporation into working circuitry.

At present, the phase-locked loop is used to decode multiple command signals transmitted over a single pair of conductors and, as such, is available from Psyonics as

Table 1

Sources of Information on Theory and Practice in Circuits Discussed

Article Information

Cohen, 1975

Goodman, 1964

Gray, 1974

Graeme, Tobey, and

Huelsman, 1971

Jorgensen, 1974

Lancaster, 1973

Lancaster, 1974

Lancaster, 1975a, b

Portune, 1975

Prensky, 1975

Waite, 1975

Wiklund, 1973;
Theory of phase-locked loop operation. General discussion of fulter characteristics. Formulae and schematic diagrams for low-, high-, and bandpass passive filters.

General theory of active filter design using operational amplifiers. High-level technical discussion with full mathematical treatment (Chapter 8). High-level discussion of operational amplifier theory and practice (Appendices $A$ and B).

Practical circuit for midaudio range active bandpass filter. Formulae given for calculating values of feedback circuit components.

Low-level technical discussion of operational amplifier theory and practice. Technician-level discussion of theory and practice in general active filter design. Technician-level discussion of theory and practice in design of active bandpass filters. Table of component values for designing bandpass filters.

Technician-level discussion of opera tional amplifier theory and practice. Simple exposition of operation of feedback network in active filters. Low-level technical discussion of operational amplifier theory and practice. Technician-level construction article on EMG feedback circuit. Circuit theory and practical construction methods well presented. Simple exposition of EMG theory.

Practical circuit for building single- or double-ended regulated power supplies. 
Table 2

Commercial Sources of Components, Power Supplies, and Finished Circuits

\begin{tabular}{|c|c|c|c|}
\hline Source & Address & Items & Literature \\
\hline Circuit Specialists Co. & $\begin{array}{l}\text { P.O. Box } 3047 \\
\text { Scottsdale, AZ } 85257\end{array}$ & $\begin{array}{l}\text { Operational amplifici integrated } \\
\text { circuits. Integrated circuit voltage } \\
\text { regulators. }\end{array}$ & $\begin{array}{l}\text { Free catalog containing reprints } \\
\text { of manufacturers' data sheets } \\
\text { and application notes. }\end{array}$ \\
\hline Delta Electronics Co. & $\begin{array}{l}\text { P.O. Box } 1 \\
\text { Lynn, MA } 01903\end{array}$ & $\begin{array}{l}\text { Precision fixed resistors. Precision } \\
\text { multiturn potentiometers. }\end{array}$ & Free catalog. \\
\hline Electroscience Mart, Inc. & $\begin{array}{l}119 \text { Foster Strcet } \\
\text { Peabody, MA } 01960\end{array}$ & $\begin{array}{l}\text { Regulated power supplies (single- } \\
\text { and double-ended). }\end{array}$ & Free catalog. \\
\hline $\begin{array}{l}\text { Leasametric/Metric } \\
\text { Resources Corp. }\end{array}$ & $\begin{array}{l}822 \text { Airport Boulvard } \\
\text { Burlingame, CA } 94010\end{array}$ & $\begin{array}{l}\text { Sales and lease of new and used } \\
\text { high-quality filter systems from } \\
\text { various manufacturers. }\end{array}$ & liree catalog. \\
\hline Poly Paks, Inc. & $\begin{array}{l}\text { P.O. Box } 942 \\
\text { South Lynnfield, MA } 01940\end{array}$ & $\begin{array}{l}\text { Operational amplifier integrated } \\
\text { circuits. Regulated power supplies. } \\
\text { Precision multiturn potentiometers. }\end{array}$ & Iree catalog. \\
\hline Psyonics & $\begin{array}{l}\text { 73-C Phelps Avenue } \\
\text { New Brunswick, NJ } 08901\end{array}$ & $\begin{array}{l}\text { TED-1 through TED-7 phase-locked } \\
\text { loop single or multiple channel tone } \\
\text { decoder (one to seven channels). }\end{array}$ & $\begin{array}{l}\text { Information brochure available } \\
\text { on request. }\end{array}$ \\
\hline Radio Shack, Inc. & $\begin{array}{l}\text { Various local stores and } \\
\text { franchises. }\end{array}$ & $\begin{array}{l}\text { Operational amplifier integrated } \\
\text { circuits. Phase-locked loop inte- } \\
\text { grated circuits. Integrated circuit } \\
\text { voltage regulators. }\end{array}$ & $\begin{array}{l}\text { Free catalog. Pin callout and } \\
\text { specifications for each item } \\
\text { listed on its package. } 567 \text { phase- } \\
\text { locked loop package includes } \\
\text { detailed application sheet. }\end{array}$ \\
\hline $\begin{array}{l}\text { Rockland Systems } \\
\text { Signetics }\end{array}$ & West Nyack, NY 10994 & High-quality filter systems. & Free catalog. \\
\hline Solid Stato Suctomelu & $\begin{array}{l}\text { Sil last Arques Avenue } \\
\text { Sunnyvale, CA } 94086\end{array}$ & $\begin{array}{l}\text { Manufacturers of operational ampli- } \\
\text { fier and phase-locked loop } \\
\text { integrated circuits, sold through } \\
\text { franchised dealers. }\end{array}$ & $\begin{array}{l}\text { Specification sheets and appli- } \\
\text { cation notes available for } \\
\text { specific integrated circuits free } \\
\text { upon request. }\end{array}$ \\
\hline Solid State Systems, Inc. & $\begin{array}{l}800 \text { North Providence Road } \\
\text { Columbia, MO } 65201\end{array}$ & $\begin{array}{l}\text { Operational amplifier integrated } \\
\text { circuits. Phase-locked loop inte- } \\
\text { grated circuits. Ancillary circuit } \\
\text { hardware. }\end{array}$ & $\begin{array}{l}\text { Free catalog. Manufacturers' } \\
\text { specification sheets and appli- } \\
\text { cation notes provided free upon } \\
\text { request, with purchase of cata- } \\
\text { loged solid state items. }\end{array}$ \\
\hline Sprague Products Co. & $\begin{array}{l}81 \text { Marshall Street } \\
\text { North Adams, MA } 01247\end{array}$ & $\begin{array}{l}\text { Type PP polypropylene film and } \\
\text { Type PM polycarbonate film close- } \\
\text { tolerance }( \pm 5 \%) \text { capacitors, sold } \\
\text { through local franchised dealers. }\end{array}$ & $\begin{array}{l}\text { Cross-reference guide } \mathrm{C}-873 \text { on } \\
\text { capacitors listed available free } \\
\text { upon request. }\end{array}$ \\
\hline
\end{tabular}

a commercial device deisgned for use with a tape recorder (Table 2).

The decision whether to buy or to build detection devices will be mainly economic. Commercially available filters are quite expensive ( $\$ 395$ to $\$ 1875)$ and are designed for much more stringent applications than are usually found in behavioral research. A perfectly satisfactory bandpass filter (Thor, Ghiselli, \& Wilson, 1973) was built at the Johnstone laboratory for less than $\$ 50$ parts cost, including power supply. On the other hand, filter construction should not be attempted unless the builder has considerable technical skill and a good fundamental knowledge of theory, as well as access to an oscilloscope, a good multimeter, and an accurately calibrated signal generator. Closely matched resistors (or potentiometers) and capacitors are required in filter construction, as is a precision double-ended power supply. Sources of these components are shown in Table 2. Phase-locked loop circuits are much lower in price (ca. $\$ 35$ per unit parts cost, including power supply) and are much easier to assemble and to calibrate. As with the bandpass filter, access to an oscilloscope, a multimeter, and a well calibrated signal generator is essential for success in calibrating the phase-locked loop circuit.

\section{REFERENCES}

Barfield, R. J., \& Geyer, L. A. Sexual behavior: UItrasonic postejaculatory song of the male rat. Science, $1972,176,1349$. 1350.

Cohen, H. How phase-locked loops work. Popular Electronics, $1975,7,32-33$.

Goodman, $\dot{B}$. The radio amateur's handbook. Newington, Conn.: American Radio Relay League, 1964 .

Graeme, J. G., Tobey, G. E., \& Huelsman, L. P. Operational amplifiers, design and applications. New York: McGrawHill, 1971 .

Gray, S. B. Carbon mike simulator. In J. S. Martin, P. L. Dexnis S. B. Gray, J. Apter. \& J. Medler (Eds.), 101 electronic projects for under \$15. New York: Davis Publications, 1974.

Helmer, R. J. Modulator and filter circuits for EEG biofeedback. Behavior Research Methods \& Instrumentation, 1975, 7.
15-18.

Jorgensen, L. Introducing ... op amp. In J. S. Martin, P. L. Dex nis, S. B. Gray, J. Apter, \& J. Medler (Eds.), 101 electronic projects for under \$15. New York: Davis Publications, 1974.

Kapuzinski, D. A., \& Rosenquist, H. S. A brief history of the voice key. Proceedings, 81 st Annual Convention, APA, 1973 , 8. $941-942$.

Lancaster, D. How active filters work. Radio-Electronics, 1973 , 44, 42-43.

Lancaster, $D$. Active bandpass filters. Radio-Electronics, 1974 , $45,40-41$.

Lancaster, D. Understanding the op amp. Radio-Electronics. $1975,46,51-58$. (a)

Lancaster, D. Understanding the op amp. Part II. Radio-Electronics, $1975,46,42-44$, (b)

Morgret, M. K. An apparatus for the detection and counting of mouse squeals. Behavior Research Methods \& Instrumentation, $1972,4,21-23$. 
Paskewitz, D. A. A hybrid circuit to indicate the presence of alpha activity. Psychophysiology, 1971, 8, 107-112.

Portune, J. E. Active filter sharpens $\mathrm{CW}$ reception. Popular Electronics, 1975, 7, 49-51.

Prensky, S. D. Getting started with op amps. Popular Electronics, $1975,7,46-48$.

Rogers, P. L., Scherer, K. R., \& Rosenthal, R. Content filtering human speech: A simple electronic system. Behavior Research Methods \& Instrumentation, 1971, 3, 16-18

Rouse, L. O. Strobe trigger, compound alpha filter, and phase coherence detector for EEG biofeedback. Behavior Research Methods Instrumentation, 1974, 6, 335-337.

Thor, D. H., Ghiselli, W. B., \& Wilson, L. D. Vocalization as an objective measure of shock-elicited social aggression in rats. Animal Learning \& Behavior, 1973, 1, 263-267.

Thorsheim H. I., Anderson, D. E., \& Schultz, L. C. An inexpensive circuit for beta, alpha, theta, or delta EEG biofeedback. Behavior Research Methods \& Instrumentation, 1974, 6. 33-36.

Waite, M. Build a muscle feedback monitor. Popular Electronics, $1975,7,39-42$.

Wiklund, J. B. Build the little giant power supply Populax Electronics, 1973, 5, 62-64.

(Received for publication June 3, 1975; revision received August 8,1975 .) 